\title{
Role of lipegfilgrastim in the management of chemotherapy-induced neutropenia [Corrigendum]
}

Hoggatt J, Tate TA, Pelus LM. Int J Nanomed. 2015;10:

$2647-2652$.

In this article, Lipegfilgrastim was referred to as a "longacting biosimilar filgrastim". The term "biosimilar" was used too broadly in this case, as Lipegfilgrastim was not approved under the biosimilar classification by the EMA. Rather, lipegfilgrastim has an active substance that is similar to filgrastim, with similar pharmacokinetics, receptor binding affinity, safety and efficacy as pegfilgrastim.

\section{Publish your work in this journal}

The International Journal of Nanomedicine is an international, peerreviewed journal focusing on the application of nanotechnology in diagnostics, therapeutics, and drug delivery systems throughou the biomedical field. This journal is indexed on PubMed Central, MedLine, CAS, SciSearch ${ }^{\circledR}$, Current Contents ${ }^{\circledR} /$ Clinical Medicine,
Journal Citation Reports/Science Edition, EMBase, Scopus and the Elsevier Bibliographic databases. The manuscript management system is completely online and includes a very quick and fair peer-review system, which is all easy to use. Visit http://www.dovepress.com/ testimonials.php to read real quotes from published authors. submit your manuscript | www.dovepress.com

Dovepress

http://dx.doi.org// 0.2147/IJN.S87133 